\title{
PENGARUH LATIHAN THREE CONE DRILL, FOUR CONE DRILL, DAN FIVE CONE DRILLTERHADAP KELINCAHAN (AGILITY) DAN KECEPATAN (SPEED)
}

\author{
Rahman Diputra \\ Penjaskesrek Universitas Nusantara PGRI Kediri \\ rahmandiputra@unpkediri.ac.id
}

\begin{abstract}
Abstrak
Tujuan dari penelitian ini yaitu untuk menganalisis tentang: (1) pengaruh pemberian three cone drill terhadap kelincahan (agility) dan kecepatan (speed); (2) pengaruh pemberian four cone drill terhadap kelincahan (agility) dan kecepatan (speed); (3) pengaruh pemberian five cone drill terhadap kelincahan (agility) dan kecepatan (speed); (4) manakah yang berpengaruh lebih besar antara latihan three cone drill, four cone drill, five cone drill dalam meningkatkan kelincahan (agility) dan kecepatan (speed). Sasaran penelitian ini adalah peserta SSB se-Kecamatan Pare kelompok umur 16-17 tahun dengan jumlah sampel sebanyak 45 peserta.

Jenis penelitian yang digunakan adalah kuantitatif dengan metode eksperimen. Rancangan penelitian ini menggunakan pre and post test design, dan analisis data menggunakan Anova. Proses pengambilan data dilakukan dengan menggunakan tes lari model Z untuk kelincahan dan lari 30 meter untuk kecepatan pada saat pretest dan posttest. Selanjutnya data hasil penelitian dianalisis dengan menggunakan bantuan SPSS seri 17.0.

Hasil penelitian menunjukkan: (1) Nilai Sig. sebesar 0,000 lebih kecil dari $0,05(p<0,05)$. Dengan kata lain terdapat pengaruh yang signifikan latihan three cone drill terhadap peningkatan kelincahan (agility) dan kecepatan (speed); (2) Nilai Sig. sebesar 0,000 lebih kecil dari $0,05(\mathrm{p}<0,05)$. Dengan kata lain terdapat pengaruh yang signifikan four cone drill terhadap peningkatan kelincahan (agility) dan kecepatan (speed); (3) Nilai Sig. sebesar 0,000 lebih kecil dari $0,05(p<0,05)$. Dengan kata lain terdapat pengaruh yang signifikan five cone drill terhadap peningkatan kelincahan (agility) dan kecepatan (speed).

Berdasarkan analisis diatas dapat disimpulkan bahwa terdapat pengaruh yang signifikan pada latihan three cone drill, four cone drill, five cone drill terhadap peningkatan kelincahan (Agility) dan kecepatan (Speed). Latihan five cone drill lebih optimal dalam meningkatkan kelincahan (agility) dan latihan three cone drill lebih optimal dalam meningkatkan kecepatan (speed).
\end{abstract}

Kata kunci: Cone Drill, Three Cone Drill, Four Cone Drill, Five Cone Drill, Kelincahan, Kecepatan. 


\section{PENDAHULUAN}

Sepakbola adalah cabang olahraga yang sudah lama berkembang dan populer di Indonesia. Sepakbola juga merupakan salah satu cabang olahraga yang paling diminati oleh masyarakat Indonesia. Hal tersebut terbukti dengan banyaknya klub di Indonesia dan banyaknya penonton disetiap pertandingan liga Indonesia. Sporis dkk (2011) juga menyatakan bahwa sepakbola merupakan permainan beregu yang paling populer di dunia, yang dimainkan dan ditonton oleh berjuta-juta orang. Namun hal tersebut tidak sebanding dengan prestasi yang didapatkan Indonesia ditingkat Internasional meskipun sepakbola adalah olahraga yang paling digemari di Indonesia.

Permainan sepakbola adalah permainan yang membutuhkan gerakan tubuh yang sangat cepat yang ditentukan oleh situasi dalam pertandingan (Kapidzic dkk, 2011: 29). Oleh karena itu untuk menunjang pergerakan yang cepat dibutuhkan kecepatan dan kelincahan yang baik. Sesuai dengan pendapat Young (2001: 315) yang menyatakan bahwa disaat berolahraga kecepatan dan kelincahan berperan penting untuk merubah arah, baik untuk mengejar atau menghindari lawan serta bereaksi terhadap pergerakan bola. Milanovic, dkk (2011) juga berpendapat bahwa kelincahan adalah sangat penting dalam futsal dan sepak bola dan itu merupakan karakteristik umum. Kelincahan adalah kemampuan secara efektif dan efisien mengubah arah misalnya, kemampuan untuk mengkoordinasikan tugas-tugas olahraga tertentu (seperti menghindari pemain lawan, membawa bola dan mengevaluasi skema pertahan) (Barnes, tanpa tahun: 10). Miller dkk (dalam Sporis dkk, 2010:66) juga berpendapat bahwa kelincahan merupakan kemampuan seorang atlet untuk mengubah arah, membuat cepat berhenti, dan melakukan gerakan cepat, halus, efisien dan berulang-ulang. Menurut Holmberg (2009: 73) kelincahan (agility) dapat didefinisikan sebagai keterampilan fisik yang memungkinkan individu dengan cepat dan efisien mengubah arah, mempercepat, dan memperlambat dalam upaya untuk bereaksi dengan tepat.

Apabila setiap pemain sepakbola memiliki kecepatan dan kelincahan (agility) yang baik tentunya akan dapat mendukung pergerakan pemain seperti mengejar atau menghindari lawan serta bereaksi terhadap pergerakan bola. 
Menurut Harsono (1993: 14) memberi rambu-rambu dalam mengembangkan agilitas adalah bentuk-bentuk latihan yang mengharuskan orang untuk bergerak dengan cepat dan mengubah arah dengan tangkas dan dalam melakukan aktivitas tersebut dia juga tidak boleh kehilangan keseimbangan dan harus sadar posisi tubuhnya. Oleh karena itu, didalam penelitian digunakan kerucut (cone)sebagai rambu-rambu untuk latihan kecepatan dan kelincahan. Sesuai dengan pendapat Sandler (2002) kerucut atau cone adalah penanda perubahan arah.

Cone drill adalah suatu bentuk latihan yang menjadikan kerucut atau cone sebagai batas dan rintangan pada saat melakukan suatu gerakan dengan tujuan untuk meningkatkan kelincahan. Cone drill merupakan cara yang baik untuk latihan pada kecepatan dan perubahan arah (Griffin football, 2011: 69). Latihan dapat dilakukan di mana saja, latihan ini paling efektif dilakukan di lapangan sepakbola sesuai dengan karakter permainan sepakbola tersebut dan akan membantu untuk menjalankan latihan yang lebih khusus dan efektif (Griffin football, 2011: 69). Dengan menambahkan kerucut atau cone memungkinkan untuk kombinasi yang berbeda dari gerakan dan meningkatkan kompleksifitas latihan (http://www.humankinetics.com/excerpts/excerpts/threecone-drills). Bentuk-bentuk latihan cone drill diantaranya adalah three cone drill, four cone drill, dan five cone drill. Latihan dengan menggunakan three cone drill, four cone drill, dan five cone drill diharapkan dapat meningkatkan kelincahan pemain sepakbola. Berdasarkan pada uraian di atas peneliti ingin melakukan percobaan dengan menerapkan latihan three cone drill, four cone drill, dan five cone drill untuk meningkatkan kelincahan pemain sepakbola.

\section{KAJIAN PUSTAKA}

Untuk meraih suatu prestasi dalam sepakbola tentunya tidaklah didapat dari cara yang instan, tetapi perlu adanya suatu proses untuk menuju kesana. Salah satu proses yang harus dilalui ialah latihan dengan tekun dan kerja keras. Reilly (2005) menyatakan bahwa latihan adalah bagian yang terpenting untuk mempersiapkan kompetisi olahraga. Latihan adalah suatu gerakan fisik dan atau aktivitas mental yang dilakukan secara sistematis dan berulang-ulang (repetitive) dalam jangka waktu (durasi) lama, dengan pembebanan yang meningkat secara progresif dan individual, yang bertujuan untuk memperbaiki 
sistem serta fungsi fisiologis dan psikologis tubuh agar pada waktu melakukan aktivitas olahraga dapat mencapai penampilan optimal (Nala, 1998: 1). Menurut Kent (Roesdiyanto dan Budiwanto, 2008: 16) latihan atau training merupakan suatu program latihan fisik yang direncanakan untuk mempelajarai keterampilan, memperbaiki kesegaran jasmani, dan terutama untuk mempersiapkan atlet dalam suatu pertandingan penting.

Tujuan latihan dalam olahraga adalah untuk memperbaiki kemampuan teknik (keterampilan) dan penampilan atlet sesuai dengan bidang kebutuhan dalam olahraga spesialisasi, Nala (1998: 4). Sedangkan menurut Menurut Hadisasmita dan Syarifuddin (1996: 128) bahwa tujuan utama latihan untuk membantu calon atlet meningkatkan keterampilan dan prestasi olahraganya semaksimal mungkin.

Kelincahan meupakan komponen kondisi fisik yang didalamnya terdiri komponen kondisi fisik yang lain. Menurut Harsono (2001: 22) kelincahan adalah koordinasi dari kecepatan, kekuatan, kecepatan reaksi, flexibility dan koordinasi neuromuscular. Sedangkan Menurut Lutan dkk, (1998) kelincahan (agility) adalah kemampuan seseorang untuk dapat mengubah arah dengan cepat dan tepat pada waktu bergerak tanpa kehilangan keseimbangan. Pernyataan tesebut sependapat dengan Twist dan Benickly (dalam Bal dkk, 2011: 272) yang mengatakan bahwa agility adalah kemampuan untuk mempertahankan kontrol posisi tubuh saat mengubah arah dengan cepat selama serangkaian gerakan. Sehingga kelincahan sangat penting untuk olahraga yang membutuhkan kemampuan adaptasi yang tinggi terhadap perubahan-perubahan situasi dalam pertandingan.

Agility is "the ability to stop, start, and change the direction of the body or body parts rapidly under kontrol" Baechle 1994 (Peebles, 2009). In this light agility is commonly defined as an effective and quick coupling of braking, changing directions and accelerating again while maintaining motor kontrol in either a vertical or horizontal direction Verstegen 2001 (Peebles, 2009). Dari pernyataan di atas dapat diketahui menurut Baechle dan Vestegen, kelincahan merupakan kemapuan untuk berhenti, memulai dan mengubah arah gerak badan atau bagian tubuh secara berulang dibawah kontrol. Sedangkan menurut Drabik (Peebles, 2009) periode penting untuk meningkatkan kelincahan berada 
direntangan sekitar usia 9-12 tahun, dengan kompleksifitas dan spesifikasi yang dimulai dari usia sekitar 16-17 tahun.

Dari penjelasan para ahli dapat ditarik kesimpulan bahwa kelincahan adalah kemampuan untuk bergerak mengubah arah dan posisi dengan cepat dan tepat sehingga memberikan kemungkinan seseorang untuk melakukan gerakan ke arah yang berlawanan dan mengatasi situasi yang dihadapi lebih cepat tanpa kehilangan keseimbangan.

Menurut Hoffman (2006: 107) bahwa kecepatan adalah kemampuan untuk melaksanakan suatu pergerakan dengan waktu yang secepat mungkin. Sedangkan menurut Sukadiyanto dan Muluk (2011: 116) kecepatan merupakan salah satu kemampuan dasar biomotorik yang diperlukan dalam setiap cabang olahraga. Kecepatan merupakan laju gerakan otot, baik untuk bagian-bagian tubuh (lengan, tangan, dan tungkai) maupun untuk seluruh tubuh (seluruh badan berpindah). Menurut Roesdiyanto dan Budiwanto (2008: 55) bahwa kecepatan (speed) adalah jarak tempuh per satuan waktu yang diukur dengan menit atau skala kuantitas; kecepatan adalah kemampuan melakukan gerakan dalam periode waktu yang pendek. Sedangkan Sajoto (1988: 58) memberikan pengertian bahwa kecepatan (speed) adalah kemampuan seseorang dalam melakukan gerakan berkesinambungan dalam bentuk yang sama, dalam waktu yang sesingkat-singkatnya. Kecepatan juga sangat bermanfaat untuk memotong pergerakan maupun umpan lawan (Widodo, 2007: 22). Tujuan dari latihan kecepatan adalah meningkatkan kemampuan pemain untuk bertindak cepat dalam situasi dimana kecepatan sangat penting (Reilly, 2006: 57).

Cone drill adalah suatu bentuk latihan yang menjadikan kerucut atau cone sebagai batas dan rintangan pada saat melakukan gerakan dengan tujuan untuk meningkatkan kelincahan. Griffin football (2011: 69) Cone drill merupakan cara yang baik untuk latihan pada kecepatan dan perubahan arah. Latihan dapat dilakukan di mana saja, latihan ini paling efektif dilakukan di lapangan sepakbola dan akan membantu untuk menjalankan latihan yang lebih khusus dan efektif (Griffin football 2011: 69). Menambahkan kerucut atau cone memungkinkan untuk kombinasi yang berbeda dari gerakan dan meningkatkan kompleksifitas latihan (http://www.humankinetic.com/excerpts/excerpts/threecone-drills). 
Bentuk-bentuk latihan cone drill diantaranya adalah three cone drill, four cone drill, dan five cone drill. Three Cone drill adalah suatu bentuk latihan yang menjadikan tiga kerucut atau cone sebagai batas dan rintangan pada saat melakukan suatu gerakan dengan tujuan untuk meningkatkan kelincahan. FourCone drill adalah suatu bentuk latihan yang menjadikan empat kerucut atau cone sebagai batas dan rintangan pada saat melakukan suatu gerakan dengan tujuan untuk meningkatkan kelincahan. Five Cone drill adalah suatu bentuk latihan yang menjadikan lima kerucut atau cone sebagai batas dan rintangan pada saat melakukan suatu gerakan dengan tujuan untuk meningkatkan kelincahan.

\section{METODE PENELITIAN}

Penelitian ini menggunakan pendekatan penelitian kuantitatif. Jenis penelitian yang digunakan tergolong penelitian eksperimen. Desain penelitian ini adalah desain eksperimen semu (quasi experimental design) dengan rancangan penelitian menggunakan Random assigment-experimental grouppretest-experimental treatment-posttest.

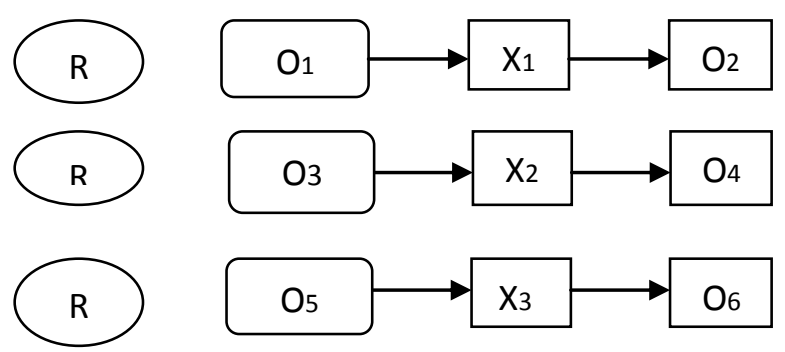

Keterangan:
R : Random
O1 : Tes awal (pre-test) kelompok 1
O2 : Tes awal (post-test) kelompok 2
O3 : Tes awal (pre-test) kelompok 3
O4 : Tes awal (post-test) kelompok 4
O5 : Tes awal (pre-test) kelompok 5
O6 : Tes awal (post-test) kelompok 6
K1 : Kelompok 1 (eksperimen)
K2 : Kelompok 2 (eksperimen)
K3 : Kelompok 3 (eksperimen)
X1 : Perlakuan dengan latihan three cone drill 


\section{X2 : Perlakuan dengan latihan four cone drill \\ X3 : Perlakuan dengan latihan five cone drill}

\section{POPULASI DAN SAMPEL PENELITIAN}

Populasi merupakan wilayah generalisasi objek atau subjek yang mempunyai kualitas dan karakteristik tertentu yang ditetapkan oleh peneliti untuk dipelajari dan kemudian ditarik kesimpulan (Sugiyono, 2010: 80).Populasi dalam penelitian ini adalah peserta SSB se-Kecamatan Pare dengan jumlah 150 peserta

Dalam penelitian ini peneliti mengambil sampel sebanyak 45 peserta dari jumlah populasi dengan menggunakan teknik simple random sampling. Simple random sampling merupakan teknik sampling yang memberikan peluang yang sama bagi individu yang menjadi anggota populasi untuk dipilih menjadi anggota sampel (Maksum, 2012: 55). Ordinal pairing merupakan salah satu cara pengelompokkan sampel dengan menggunakan sistem urutan yang menggambarkan adanya peringkat (Riyanto, 2007: 39). Teknik pengelompokan sampel ke dalam tiga kelompok dilakukan secara ordinal pairing. Adapun pembentukan grup dalam penelitian ini akan membuat tiga kelompok ialah kelompok eksperimen 1, eksperimen 2, dan kelompok eksperimen 3. Berdasarkan teknik ordinal pairing, maka sampel dalam penelitian ini akan dikelompokkan sebagai berikut kelompok $\mathrm{I}=15$ (latihan three cone drill), kelompok II = 15 orang (latihan four cone drill) dan kelompok III= 15 orang (latihan five cone drill).

\section{Instrumen Penelitian}

1. Pengukuran kelincahan menggunakan tes lari model "Z"(Widodo, 2007:140).

2. Pengukuran kecepatan menggunakan tes lari 30 meter(Sriundy, 2010:105).

\section{Tempat dan Waktu Penelitian}

Penelitian dilakukan di lapangan Tulungrejo Pare Kabupaten Kediri, Jawa Timur. Penelitian ini dilaksanakan selama 10 minggu dengan rincian, minggu pertama dilakukan tahap persiapan pelaksanaan penelitian dan melakukan pre-test kelincahan dan kecepatan untuk mengetahui data awal sebelum melaksanakan latihan.

Dalam penelitian ini pemberian perlakuan (treatment) dilakukan selama 8 minggu. Dengan frekuensi 24 kali pertemuan yang dilaksanakan 3 kali dalam 
seminggu. Kemudian minggu terakhir (minggu ke-10) dilakukan posttest untuk mengetahui data hasil setelah diterapkan perlakuan (treatment) atau data akhir.

\section{Teknik Analisis Data}

Sesuai dengan jenis penelitian yang digunakan dalam penelitian ini, maka analisis statistik yang digunakan untuk mengetahui pengaruh latihan three cone drill, four cone drill, five cone drilterhadap kelincahan dan kecepatan pada peserta SSB se-Kecamatan Pare, adalah menggunakan analysis of variance(ANOVA) dan uji Post Hoc.

\section{HASIL PENELITIAN}

Deskripsi data yang akan disajikan berupa data hasil tes kecepatan dan kelincahan sebelum (pretest) dan sesudah (posttest) diberikan perlakuan pada masing-masing kelompok yang meliputi: kelompok I latihan three cone drill kelompok II latihan four cone drill, dan kelompok IIIfive cone drill. Penelitian ini dilakukan pada peserta SSB se-Kecamatan Pare kelompok umur 16-17 tahun sebanyak 45mahasiswa dan dibagi menjadi 3 kelompok, dan masing-masing kelompok berjumlah 15 orang.

Dalam penelitian ini akan dibahas hasil penelitian yang mencakup deskripsi data, analisis data, pengujian prasyarat analisis, dan pengujian hipotesis berdasarkan hasil dan interprestasi data dengan menggunakan Microsoft Excel 2010 dan SPSS 17.

\section{Analisis}

1. DataTes Awal dan Tes Akhir Kelompok Eksperimen I

\begin{tabular}{cccccc}
\hline & Nama & \multicolumn{2}{c}{ Kelincahan } & \multicolumn{2}{c}{ Kecepatan } \\
\cline { 2 - 6 } & & $\begin{array}{c}\text { Pret } \\
\text { est }\end{array}$ & Posttest & Pretest & $\begin{array}{c}\text { Postte } \\
\text { st }\end{array}$ \\
\hline 1. & DN & 4.67 & 4.14 & 4.22 & 3.69 \\
\hline 2. & AE & 4.69 & 4.23 & 4.59 & 4.14 \\
\hline 3. & JK & 4.81 & 4.44 & 4.25 & 3.74 \\
\hline 4. & AS & 5.04 & 4.30 & 4.73 & 4.22 \\
\hline 5. & DSM & 5.12 & 4.50 & 4.46 & 3.79 \\
\hline 6. & FB & 5.12 & 4.52 & 4.47 & 3.78 \\
\hline
\end{tabular}




\begin{tabular}{lccccc}
\hline 7. & AD & 4.98 & 4.41 & 4.72 & 4.11 \\
\hline 8. & JA & 5.01 & 4.44 & 4.76 & 4.18 \\
\hline 9. & MD & 5.27 & 4.81 & 4.46 & 3.77 \\
\hline 10. & AES & 5.21 & 4.65 & 4.71 & 4.15 \\
\hline 11. & ASB & 5.44 & 4.67 & 4.46 & 3.82 \\
\hline 12. & AF & 5.29 & 4.78 & 4.99 & 4.34 \\
\hline 13. & DM & 5.15 & 4.56 & 5.18 & 4.61 \\
\hline 14. & FH & 5.41 & 4.73 & 5.21 & 4.65 \\
\hline 15. & WP & 5.80 & 5.15 & 4.71 & 4.19 \\
\hline Rerata & 5.1233 & 4.66133 & 4.55533 & 4.0786 \\
\hline $\begin{array}{l}\text { Standart } \\
\text { deviasi }\end{array}$ & 0.2995 & 0.25595 & 0.29616 & 0.3082 \\
\hline Peningkatan & $11.09 \%$ & & $12.5 \%$ \\
\hline
\end{tabular}

Pada hasil tabel di atas menunjukkan adanya peningkatan kelincahan (agility) yang signifikan setelah diberi perlakuan selama delapan minggu. Hal ini dapat dilihat dari rerata tes akhir sebesar 4.661333dan rerata tes awal sebesar 5.12333. Hal ini terjadi pada peningkatan persentase variabel kelincahan (agility) dari pretest ke posttest sebesar $11.09 \%$. Demikian pula hasil perolehan data variabel kecepatan (speed) yang menunjukkan adanya peningkatan kecepatan (speed) yang signifikan setelah diberi perlakuan selama delapan minggu. Hal ini dapat dilihat dari rerata tes akhir sebesar 4.07867yang lebih kecil dari rerata tes awal sebesar 4.555333. Hal ini terjadi pada peningkatan persentase variabel kecepatan dari pretest (tes awal) ke posttest (tes akhir) sebesar $12.5 \%$. Perolehan hasil tes kelincahan dengan menggunakan tes lari model " $Z$ "dan kecepatan diperoleh menggunakan tes lari 30 meter.

2. DataTes Awal dan Tes Akhir Kelompok Eksperimen II

\begin{tabular}{cccccc}
\hline \multirow{2}{*}{ No. } & \multirow{2}{*}{ Nama } & \multicolumn{2}{c}{ Kelincahan } & \multicolumn{2}{c}{ Kecepatan } \\
\cline { 3 - 6 } & & Pretest & Posttest & Pretest & Posttest \\
\hline 1. & AH & 4.78 & 4.1 & 4.24 & 3.83 \\
\hline 2. & AF & 4.68 & 3.97 & 4.59 & 4.14 \\
\hline
\end{tabular}




\begin{tabular}{cccccc}
\hline 3. & KT & 4.96 & 4.29 & 4.36 & 3.85 \\
\hline 4. & DR & 5.04 & 4.16 & 4.41 & 3.94 \\
\hline 5. & TK & 4.88 & 4.09 & 4.70 & 4.13 \\
\hline 6. & FD & 4.9 & 4.21 & 4.75 & 4.26 \\
\hline 7. & FL & 5.1 & 4.21 & 4.57 & 4.06 \\
\hline 8. & BG & 5.16 & 4.32 & 4.54 & 4.06 \\
\hline 9. & KR & 5.06 & 4.44 & 4.76 & 4.17 \\
\hline 10. & MF & 5.15 & 4.49 & 4.78 & 4.31 \\
\hline 11. & ASM & 5.06 & 4.34 & 5.07 & 5.53 \\
\hline 12. & MFT & 5.37 & 4.73 & 4.79 & 4.24 \\
\hline 13. & AR & 5.14 & 4.3 & 5.35 & 4.88 \\
\hline 14. & DA & 5.22 & 4.36 & 5.4 & 4.95 \\
\hline 15. & AM & 5.76 & 5.03 & 4.23 & 4.69 \\
\hline Rerata & & 5.084 & 4.336 & 4.769333 & 4.26933 \\
\hline Standart deviasi & 0.25640 & 0.26573 & 0.35302 & 0.34792 \\
\hline Peningkatan & \multicolumn{2}{c}{$14,71 \%$} & \multicolumn{2}{c}{$10,48 \%$} \\
\hline
\end{tabular}

Perolehan data variabel kelincahan (agility) yang diperoleh dari hasil tes kelincahan kelincahan (agility) dengan menggunakantes lari model " $Z$ " menunjukkan adanya penigkatan kelincahan (agility)yang signifikan setelah diberi perlakuan selama delapan minggu. Hal ini dapat dilihat dari rerata tes akhir sebesar 4.336yang lebih besar dari rerata tes awal sebesar 5.084 . Hal ini terjadai pada peningkatan persentase variabel kelincahan dari pretest ke posttest sebesar $14,71 \%$. Peningkatan tersebut akibat dari peningkatan setelah diberi perlakuan selama pelatihan delapan minggu dan dengan frekuensi tiga kali dalam satu minggu.

Demikian pula pada variabelkecepatan (speed), menunjukkan adanya peningkatan setelah diberi perlakuan. Hal ini dapat dilihat dari rerata tes akhir sebesar 4.26933yang lebih kecil dari rerata tes awal sebesar 4.769333. Hal ini terjadai pada peningkatan persentase variabel kecepatan (speed) dari pretest 
ke posttest sebesar 10,48 \%\%. Perolehan data hasil tes kecepatan dengan menggunakan tes lari 30 meter.

3. DataTes Awal dan Tes Akhir Kelompok Eksperimen III

\begin{tabular}{|c|c|c|c|c|c|}
\hline \multirow[b]{2}{*}{ No. } & \multirow[b]{2}{*}{ Nama } & \multicolumn{2}{|c|}{ Kelincahan } & \multicolumn{2}{|c|}{ Kecepatan } \\
\hline & & Pretest & Posttest & Pretest & $\begin{array}{c}\text { Posttes } \\
t\end{array}$ \\
\hline 1. & FN & 4.85 & 3.9 & 4.21 & 3.8 \\
\hline 2. & $\mathrm{RC}$ & 4.87 & 3.77 & 4.27 & 3.92 \\
\hline 3. & AN & 4.9 & 4.03 & 4.51 & 4.2 \\
\hline 4. & MT & 5.01 & 4.13 & 4.4 & 3.93 \\
\hline 5. & $\mathrm{ABG}$ & 5.11 & 4.22 & 4.41 & 3.99 \\
\hline 6. & $\mathrm{RD}$ & 5.18 & 3.99 & 4.37 & 3.78 \\
\hline 7. & MS & 4.91 & 4.02 & 4.84 & 4.53 \\
\hline 8. & $A G$ & 5.44 & 4.6 & 4.16 & 3.68 \\
\hline 9. & YF & 5.32 & 4.4 & 4.54 & 4.22 \\
\hline 10. & LM & 5.3 & 4.24 & 4.58 & 4.11 \\
\hline 11. & DP & 5.74 & 4.82 & 4.22 & 3.88 \\
\hline 12. & DT & 5.36 & 4.42 & 4.8 & 4.43 \\
\hline 13. & AA & 5.45 & 4.61 & 5.01 & 4.54 \\
\hline 14. & ES & 5.29 & 4.13 & 5.22 & 4.86 \\
\hline 15. & MB & 5.61 & 4.78 & 5.75 & 5.36 \\
\hline \multicolumn{2}{|c|}{ Rerata } & 5.22266 & 4.27066 & 4.61933 & 4.21533 \\
\hline \multicolumn{2}{|c|}{ Standart deviasi } & 0.27778 & 0.32232 & 0,43973 & 0.46045 \\
\hline \multicolumn{2}{|c|}{ Peningkatan } & \multicolumn{2}{|c|}{$18.23 \%$} & 8.75 & $\%$ \\
\hline
\end{tabular}

Pada hasil tabel di atas menunjukkan adanya peningkatan kelincahan (agility) yang signifikan setelah diberi perlakuan selama delapan minggu. Hal ini dapat dilihat dari rerata tes akhir sebesar 4.270667dan rerata tes awal sebesar 5.222667. Hal ini terjadi pada peningkatan persentase variabel kelincahan (agility) dari pretest ke posttest sebesar $18.23 \%$. Demikian pula hasil perolehan 
data variabel kecepatan (speed) yang menunjukkan adanya peningkatan kecepatan (speed) yang signifikan setelah diberi perlakuan selama delapan minggu. Hal ini dapat dilihat dari rerata tes akhir sebesar 4.215333yang lebih kecil dari rerata tes awal sebesar 4.619333. Hal ini terjadi pada peningkatan persentase variabel kecepatan dari pretest (tes awal) ke posttest (tes akhir) sebesar $8.75 \%$. Perolehan hasil tes kelincahan dengan menggunakan tes lari model "Z" dan kecepatan diperoleh menggunakan tes lari 30 meter.

\section{Hasil Uji Hipotesis}

\section{Pengaruh Latihan Three Cone Drills, Four Cone Drills, Five Cone Drill Terhadap Kelincahan (Agility) dan Kecepatan (Speed)}

Untuk mengetahui perbedaan variabel dependent antar kelompok digunakan analisis varians. Sebagaimana yang telah dijelaskan sebelumnya bahwa untuk menguji hipotesis dapat dilakukan setelah data berdistribusi normal dan homogen. Oleh karena kriteria tersebut telah terpenuhi maka langkah selanjutnya dapat dipergunakan analysis of variance(ANOVA). One Way Anova adalah teknik statistikparametrik yang digunakan untuk menguji perbedaan antara tiga atau lebih kelompok data (Maksum, 2012:182)

Tabel Hasil Perhitungan Uji Beda antar Kelompok Three Cone Drills, Four Cone Drills, Five Cone Drill terhadap kelincahan (Agility) dan kecepatan (Speed)

\begin{tabular}{|c|c|c|c|c|c|c|}
\hline \multicolumn{7}{|c|}{ ANOVA } \\
\hline & & $\begin{array}{l}\text { Sum of } \\
\text { Squares }\end{array}$ & $d f$ & $\begin{array}{c}\text { Mean } \\
\text { Square }\end{array}$ & $\mathrm{F}$ & Sig. \\
\hline \multirow[t]{3}{*}{ Kelincahan } & $\begin{array}{l}\text { Between } \\
\text { Groups }\end{array}$ & 1.107 & 2 & .554 & 56.345 & .000 \\
\hline & $\begin{array}{l}\text { Within } \\
\text { Groups }\end{array}$ & .413 & 42 & .010 & & \\
\hline & Total & 1.520 & 44 & & & \\
\hline \multirow[t]{3}{*}{ Kecepatan } & $\begin{array}{l}\text { Between } \\
\text { Groups }\end{array}$ & .240 & 2 & .120 & 25.279 & .000 \\
\hline & $\begin{array}{l}\text { Within } \\
\text { Groups }\end{array}$ & .199 & 42 & .005 & & \\
\hline & Total & .439 & 44 & & & \\
\hline
\end{tabular}

Berdasarkan tabeldi atas hasil perhitungan uji beda antar kelompok

menggunakan One Way Anova dapat disimpulkan bahwa terdapat hasil rerata yang berbeda antar kelompok, karena hasil perhitungan menunjukkan nilai Sig. $0,0010<$ nilai $\alpha=0,05$ dan nilai Sig. $0,000<$ nilai $\alpha=0,05$, maka dapat dikatakan 
bahwa Ho ditolak dan Ha diterima. Dengan kata lain bahwa terdapat perbedaan yang signifikan antara hasil latihan kelompok three cone drill, kelompokfour cone drill, dan kelompok five cone drill terhadap kelincahan (agility) dan kecepatan (speed).Dengan adanya perbedaan hasil rerata, maka perhitungan akan dilanjutkan dengan menggunakan Post Hoc Test.

Tabel Hasil Perhitungan Post Hoc Test three cone drill, four cone drill, five cone drill terhadap kelincahan

\begin{tabular}{|c|c|c|c|c|c|c|c|}
\hline \multirow{2}{*}{$\begin{array}{c}\text { Dependent } \\
\text { Variable }\end{array}$} & \multirow{2}{*}{$\begin{array}{c}(\mathrm{I}) \\
\text { metode_latihan }\end{array}$} & \multirow{2}{*}{$\begin{array}{c}(\mathrm{J}) \\
\text { metode_latihan }\end{array}$} & \multirow{2}{*}{$\begin{array}{c}\text { Mean } \\
\text { Difference } \\
(I-J)\end{array}$} & \multirow{2}{*}{$\begin{array}{l}\text { Std. } \\
\text { Error }\end{array}$} & \multirow{2}{*}{ Sig. } & \multicolumn{2}{|c|}{$\begin{array}{l}\text { 95\% Confidence } \\
\text { Interval }\end{array}$} \\
\hline & & & & & & $\begin{array}{l}\text { Lower } \\
\text { Bound }\end{array}$ & $\begin{array}{l}\text { Upper } \\
\text { Bound }\end{array}$ \\
\hline \multirow[t]{6}{*}{ kelincahan } & latihan 3 cone & latihan 4 cone & $-.18000^{*}$ & .03620 & .000 & -.2530 & -.1070 \\
\hline & & latihan 5 cone & $-.38400^{\star}$ & .03620 & .000 & -.4570 & -.3110 \\
\hline & latihan 4 cone & latihan 3 cone & $.18000^{*}$ & .03620 & .000 & .1070 & .2530 \\
\hline & & latihan 5 cone & $-.20400^{*}$ & .03620 & .000 & -.2770 & -.1310 \\
\hline & latihan 5 cone & latihan 3 cone & $.38400^{*}$ & .03620 & .000 & .3110 & .4570 \\
\hline & & latihan 4 cone & $.20400^{*}$ & .03620 & .000 & 1310 & .2770 \\
\hline
\end{tabular}

*. The mean difference is significant at the 0.05 level.

Berdasarkan tabel di atas menunjukkan bahwa adanya perbedaan yang signifikan diantara ketiga kelompok. Perbedaan tersebut dapat dilihat dari mean difference. Sehinga dari mean difference tersebut memberikan sebuah makna perbedaan pengaruh terhadap peningkatan kelincahan antar kelompok. Sehingga dari nilai mean difference dapat diketahui bahwa kelompok latihan five cone drill lebih optimal peningkatannya terhadap kelincahan dibandingkan dengan latihan three cone drill dan kelompok latihan four cone drill. 
Tabel Hasil Perhitungan Post Hoc Test three cone drill, four cone drill, five cone drill terhadap kecepatan

\section{Multiple Comparisons}

\begin{tabular}{|c|c|c|c|c|c|c|c|}
\hline \multirow[b]{2}{*}{$\begin{array}{l}\text { Dependent } \\
\text { Variable }\end{array}$} & \multirow{2}{*}{$\begin{array}{l}(\mathrm{I}) \\
\text { metode_la } \\
\text { tihan }\end{array}$} & \multirow{2}{*}{$\begin{array}{l}(\mathrm{J}) \\
\text { metode_lati } \\
\text { han }\end{array}$} & \multirow{2}{*}{$\begin{array}{c}\text { Mean } \\
\text { Difference } \\
(\mathrm{I}-\mathrm{J}) \\
\end{array}$} & \multirow[b]{2}{*}{$\begin{array}{l}\text { Std. } \\
\text { Error }\end{array}$} & \multirow[b]{2}{*}{ Sig. } & \multicolumn{2}{|c|}{$\begin{array}{c}95 \% \text { Confidence } \\
\text { Interval }\end{array}$} \\
\hline & & & & & & $\begin{array}{l}\text { Lower } \\
\text { Bound }\end{array}$ & $\begin{array}{l}\text { Upper } \\
\text { Bound }\end{array}$ \\
\hline \multirow[t]{6}{*}{ kecepatan } & $\begin{array}{l}\text { latihan } 3 \\
\text { cone }\end{array}$ & $\begin{array}{l}\text { latihan } 4 \\
\text { cone }\end{array}$ & $.08267^{*}$ & .02515 & .002 & .0319 & .1334 \\
\hline & & $\begin{array}{l}\text { latihan } 5 \\
\text { cone }\end{array}$ & $.17867^{*}$ & .02515 & .000 & .1279 & .2294 \\
\hline & $\begin{array}{l}\text { latihan } 4 \\
\text { cone }\end{array}$ & $\begin{array}{l}\text { latihan } 3 \\
\text { cone }\end{array}$ & $-.08267^{*}$ & .02515 & .002 & -.1334 & -.0319 \\
\hline & & $\begin{array}{l}\text { latihan } 5 \\
\text { cone }\end{array}$ & $.09600^{*}$ & .02515 & .000 & .0452 & .1468 \\
\hline & $\begin{array}{l}\text { latihan } 5 \\
\text { cone }\end{array}$ & $\begin{array}{l}\text { latihan } 3 \\
\text { cone }\end{array}$ & $-.17867^{*}$ & .02515 & .000 & -.2294 & -.1279 \\
\hline & & $\begin{array}{l}\text { latihan } 4 \\
\text { cone }\end{array}$ & $-.09600^{*}$ & .02515 & .000 & -.1468 & -.0452 \\
\hline
\end{tabular}

*. The mean difference is significant at the 0.05 level.

Berdasarkan tabel diatas menunjukkan bahwa adanya perbedaan yang signifikan diantara ketiga kelompok. Perbedaan tersebut dapat dilihat dari mean difference yang memberikan sebuah makna perbedaan pengaruh terhadap peningkatan kecepatan antar kelompok. Sehingga dari nilai mean difference dapat diketahui bahwa kelompok latihan three cone drill memberikan peningkatan yang lebih optimal dari kelompok four cone drill dan kelompok latihan five cone drill terhadap kecepatan.

\section{DISKUSI HASIL PENELITIAN}

Dari hasil penelitian yang diperoleh, maka dibuat suatu pembahasan mengenai hasil-hasil dari analisa penelitian dan perlu didiskusikan dengan teoriteori atau hasil-hasil penelitian sebelumnya yang relevan untuk dapat membuat suatu simpulan. Pembahasan disini membahas penguraian hasil penelitian tentang pemberian pengaruh latihan three cone drill, four cone drill, five cone drill terhadap kelincahan (agility) dan kecepatan (speed) pemain sepakbola. 
Permainan sepakbola adalah permainan yang membutuhkan gerakan tubuh yang sangat cepat yang ditentukan oleh situasi dalam pertandingan (Kapidzic dkk, 2011:29). Oleh karena itu untuk menunjang pergerakan yang cepat dibutuhkan kecepatan dan kelincahan yang baik. Seperti yang diungkapkan oleh Milanovic dkk, ( 2011) bahwa kelincahan adalah sangat penting dalam futsal dan sepakbola, dan itu merupakan karakteristik umum. Selain itu Holmberg (2009:73) juga menyatakan bahwa kelincahan (agility) dapat didefinisikan sebagai ketrampilan fisik yang memungkinkan individu dengan cepat dan efisien mengubah arah, mempercepat, dan memperlambat dalam upaya untuk bereaksi dengan tepat. Sehingga apabila setiap pemain sepakbola memiliki kelincahan dan kecepatan yang baik tentunya dapat mendukung pergerakan pemain seperti mengejar atau menghindari lawan serta bereaksi terhadap pergerakan bola.

Dalam kelincahan juga harus didukung dari beberapa kombinasi komponen kondisi fisik yang lain, salah satunya kecepatan (speed). Bompa (1999: 5) berpendapat, bahwa kelincahan (agility) merupakan produk dari kombinasi yang kompleks dari kecepatan, koordinasi, kelentukan, dan kekuatan. Oleh karena itu dalam latihan ini digunakan three cone drill, four cone drill, five cone drill untuk meningkatan kemampuankelincahan (agility)dan kecepatan (agility). Hal tersebut sesuai pendapat dari Griffin football (2011: 69) yang menyatakan bahwa cone drill merupakan cara yang baik untuk latihan pada kecepatan dan perubahan arah. Hasil dari penelitian ini relevan dengan hasil Griffin Football (2011), Reilly (2005), Castello dan Kreis (1993) dalam Johnson dan Bajjibabu (2012).

Kelompok program latihan three cone drill menunjukkan perbaikan pada kelincahan (agility)dan kecepatan (speed). Kemampuan kelincahan (agility)dan kecepatan (speed) kelompok latihan three cone drill meningkat dilihat dari hasil pretest dan posttest.Hasil penelitian tersebut dapat dikatakan bahwa pemberian latihanthree cone drill berpengaruhterhadap peningkatankelincahan (agility)dan kecepatan (agility). Hasil tersebut memberikan bukti nyata bahwalatihan three cone drill merupakan salah satu bentuk latihan yang bertujuan untuk meningkatkan kelincahan (agility)dan kecepatan (agility). 
Kelompok program latihan four cone drill menunjukkan perbaikan pada kelincahan (agility)dan kecepatan (speed). Kemampuan kelincahan (agility)dan kecepatan (speed) kelompok latihan four cone drill meningkat dilihat dari hasil pretest dan posttest.Hasil penelitian tersebut dapat dikatakan bahwa pemberian latihanfour cone drill berpengaruhterhadap peningkatankelincahan (agility)dan kecepatan (agility). Hasil tersebut memberikan bukti nyata bahwalatihan four cone drill merupakan salah satu bentuk latihan yang bertujuan untuk meningkatkan kelincahan (agility)dan kecepatan (agility).

Kelompok program latihan five cone drill menunjukkan perbaikan pada kelincahan (agility)dan kecepatan (speed). Kemampuan kelincahan (agility)dan kecepatan (speed) kelompok latihan five cone drill meningkat dilihat dari hasil pretest dan posttest.Hasil penelitian tersebut dapat dikatakan bahwa pemberian latihan five cone drill berpengaruh terhadap peningkatan kelincahan (agility) dan kecepatan (agility). Hasil tersebut memberikan bukti nyata bahwa latihan five cone drill merupakan salah satu bentuk latihan yang bertujuan untuk meningkatkan kelincahan (agility) dan kecepatan (agility).

Dari hasil olah data pada bab IV, dapat dikatakan bahwa pemberian program latihan three cone drill, four cone drill, five cone drill menunjukkan peningkatan yang dilihat dari hasil pretest dan posttest. Sesuai dengan hasil analisis menunjukkan bahwa latihan five cone drill mempunyai pengaruh yang lebih optimal terhadap hasil kemampuan kelincahan (agility) dan latihan three cone drill mempunyai pengaruh yang optimal terhadap hasil kemampuan kecepatan (speed) peserta SSB se-Kecamatan Pare kelompok umur 16-17 tahun. Maka dapat direkomendasikan kepada semua pelatih dan praktisi olahraga pada umumnya dan khususnya sepakbola bahwa pelatihan three cone drill, for cone drill, five cone drill sesuai dan tepat dalam meningkatkan kemampuan kelincahan (agility) dan kecepatan (speed).

\section{SIMPULAN}

Berdasarkan hasil penelitian dan pembahasan tentang pengaruh latihan three cone drill, four cone drill, five cone drill terhadap kelincahan (agility) dan kecepatan (speed), yang telah diuraikan pada bab sebelumnya maka dapat dikemukanan simpulan penelitian sebagai berikut: 
1. Terdapat pengaruh yang signifikan latihan three cone drill terhadap peningkatan kelincahan (agility).

2. Terdapat pengaruh yang signifikan latihan three cone drill terhadap peningkatan kecepatan (speed).

3. Terdapat pengaruh yang signifikan latihan four cone drill terhadap peningkatan kelincahan (agility).

4. Terdapat pengaruh yang signifikan latihan four cone drill terhadap peningkatan kecepatan (speed).

5. Terdapat pengaruh yang signifikan latihan five cone drill terhadap peningkatan kelincahan (agility).

6. Terdapat pengaruh yang signifikan latihan five cone drill terhadap peningkatan kecepatan (speed).

7. Terdapat perbedaan pengaruh yang signifikan latihan antara three cone drill, four cone drill, five cone drilterhadap kelincahan (agility) dan kecepatan (speed) serta kelompok five cone drill lebih optimal dalam meningkatkan kelincahan (agility).

8. Terdapat perbedaan pengaruh yang signifikan latihan antara three cone drill, four cone drill, five cone drilterhadap kelincahan (agility) dan kecepatan (speed) serta kelompok three cone drill lebih optimal dalam meningkatkan kecepatan (speed).

\section{SARAN}

1. Untuk meningkatkan kelincahan (agility) dan kecepatan (speed) pada atlet khususnya cabang olahraga sepakbola tidak hanya dilakukan dengan latihan konvensional, tetapi dapat dilakukan dengan metode pelatihan yang kontinyu dengan bentuk program latihan three cone drill, four cone drill, five cone drill.

2. Model latihan three cone drill, four cone drill, five cone drill dapat dikombinasikan untuk meningkatkan kelincahan (agility) dan kecepatan (speed) pada atlet sepakbola.

3. Model latihan three cone drill, four cone drill, five cone drill dapat direkomendasikan dan diterapkan pada program latihan dalam rangka peningkatan kelincahan (agility) dan kecepatan (speed) pada atlet sepakbola.

4. Bagi peneliti selanjutnya, dapat dijadikan bahan masukan dan perbandingan hasil penelitian jika memilih masalah sejenis sebagai objek penelitiannya. 


\section{DAFTAR PUSTAKA}

Bal, B.S., Kaur, P.J., and Singh, D. 2011. "Effects Of A Short Term Plyometric Training Program Of Agility In Young Basketball Players". Brazilian Journal of Biomotricity. Vol. 5 No. 4, pp. 271-278.

Barnes, M. Incorporating Agility Into an Off Season Football Program. NSCA's Performance Training Journal. Vol.5 no 4.

Hadisasmita dan Syarifuddin, A. 1996. IImu Kepelatihan Dasar.Jakarta: Depdikbud Dirjen Dikti Proyek Pendidikan Tenaga Akademik

Harsono. 1988. Coaching dan Aspek-aspek Psikologi dalam Coaching. Jakarta: Dirjen Dikti Proyek Pengembangan Lembaga Pendidikan Tenaga Kependidikan.

Harsono. 1993. Latihan Kondisi Fisik, Jakarta: Koi Pusat.

Harsono. 2001. Latihan Kondisi Fisik. Bandung: Proyek Pengembangan Lembaga Pendidikan Tenaga Kependidikan, Departemen Pendidikan dan Budaya.

Holmberg, P.H. 2009. "Agility Training for Experienced Athletes: A Dynamical Systems Approach". Strength and Conditioning Journal. Vol. 31 No. 3 Oktober 2009. pp. 73 - 78.

http//www.humankinetics.com/excerpts/excerpts/three-cone-drills.

Diakses tanggal 12 Desember 2013.

Lutan, R., Supandi., Giriwijoyo, S., Ichsan, M., Setiawan, I., Nadisah., Hidayat, I., Nurhasan. Dan Wiramihardja, K.K. 1998. Manusia dan Olahraga. Bandung: ITB dan FPOK/IKIP Bandung.

Kapidzic, A., Pojskic H., Mutatovic, M., Uzicanin, E., and Bilalic, A. 2011. Correlation of Tests for Evaluating Explosive Strength and agility of Football Player. Sport SPA. Vol 8. Issue 2. 29-34.

Maksum, A. 2012. Metodologi Penelitian dalam Olahraga. Surabaya: Unesa University Press.

Milanovic, Z. et al. 2011. "Difference in Agility Performance Between Futsal and Soccer". Sport Science. Vol 4. No 2.pp. 55-59.

Nala, N. 1998. Prinsip Pelatihan Fisik Olahraga. Denpasar: Universitas Udayana.

Pebles, J. 2009. Agility Drill: Improve Your Foot Speed And Balance. CSCS

Reilly, T. 2005.Training Specificity for Soccer. International Journal of Applied Sports Sciences, Vol. 17, No. 2, 17-25.

Reilly, T. 2007. The Sience of Training Soccer: A Scientific Approach to Developing Strehth, Speed and Endurance. USA: Routledge. 
Riyanto, Y. 2007. Metodologi Penelitian Pendidikan Kualitatif dan Kuantitatif. Surabaya: Unesa University Press.

Roesdiyanto dan Budiwanto, S. 2008. Dasar-dasar Kepelatihan Olahraga. Malang: Laboratorium IImu Keolahragaan, Jurusan IImu Keolahragaan, Universitas Negeri Malang.

Sandler, D. 2005. Sport Power Develop the Optimal, Combination of Size, Speed, Strength. America: Human Kinetics.

Sugiyono. 2010. Metode Penelitian Bisnis (Pendekatan Kuantitatif, Kualitatif dan $R \& D)$. Bandung: Alfabeta

Sporis, G., Jukic, I., Milanovic, L., And Vucetic, V. 2010. "Reliability and Factorial Validity of Agility Tests for Soccer Players". Journal of Strength and Conditioning Research. Vol. 24 No. 3 March 2010. pp. 679-689.

Sporis, G., Milanovic, Z., Trajkovic., and Joksimovic, A. 2011. Correlation Between Speed, Agility and Quickness (SAQ) in Elite Young Soccer Players. Acta Kinesiologica. 5.2: 36-41.

Sriundy, I. 2010. Pengantar Evaluasi Pengajaran. Surabaya: Unesa University Press.

Sukadiyanto dan Muluk, D. 2011. Pengantar Teori dan Metodologi Melatih Fisik. Bandung: Lubuk Agung.

Widodo, A. 2007. "Pengembangan Rangkaian Tes Fisik untuk Pemain Sepakbola". Disertasi Doktor Ilmu Keolahragaan, Universitas Negeri Surabaya.

Young, W. B., \& Sheppard, J.M. 2006. Agility Literature Review: Classifications, Training and Testing. Journal of Sports Sciences. September 2006; 24(9): 919-932. 